\title{
Footprints of Mantle-Melt Reactions Recorded in Cr-spinel from the Ronda Peridotite Massif
}

\author{
MR. IGOR GONZÁLEZ-PÉREZ SR. ${ }^{1}$, CHRISTIAN \\ MORENO ${ }^{2}$, JOSE MARÍA GONZÁLEZ-JIMÉNEZ ${ }^{3}$, \\ FERNANDO GERVILLA ${ }^{4}$ AND CLAUDIO MARCHESI ${ }^{3}$ \\ ${ }^{1}$ University of Granada CIFQ1818002 \\ ${ }^{2}$ University of Granada \\ ${ }^{3}$ Universidad de Granada \\ ${ }^{4}$ Universidad de Granada Q1818002F \\ Presenting Author: igorgonzpe@ugr.es
}

Cr-spinel $\left[\left(\mathrm{Mg}, \mathrm{Fe}^{2+}\right)\left(\mathrm{Cr}, \mathrm{Al}, \mathrm{Fe}^{3+}\right)_{2} \mathrm{O}_{4}\right]$ is a typical mineral in mantle rocks (i.e. peridotites) that has been commonly used as a straightforward indicator of the degree of mantle melting. However, mantle peridotites commonly experience more complex processes involving metamorphism and metasomatism that can overprint the primary composition of Cr-spinel. An example of the latter is found in the Ronda Ultramafic Massif where subcontinental lithospheric mantle (SCLM) peridotites have undergone several events of partial melting and melt-rock interactions.

Electron-microprobe analyses reveal unexpected differences in $\mathrm{Cr} \#=[\mathrm{Cr} /(\mathrm{Cr}+\mathrm{Al})]$ of the core of $\mathrm{Cr}$-spinel from different peridotite lithologies in some tectonometamorphic domains of the Ronda Massif. Thus, whereas Cr-spinel from lherzolites and harzburgites of the spinel-tectonite and granular spinel peridotite domains have $\mathrm{Cr} \#$ values ranging from $0.13-0.20$ (lherzolite) to 0.54-0.62 (harzburgite), these peridotite lithologies contain $\mathrm{Cr}$ spinel with overlapping $\mathrm{Cr} \#$ values (between $0.15-0.38$ ) in the plagioclase tectonite domain. $\mathrm{Cr}$-spinel in dunite from the latter domain exhibit a bimodal composition depending on the presence or absence of clinopyroxene; in clinopyroxene-free dunite $\mathrm{Cr} \#$ of $\mathrm{Cr}$-spinel varies from 0.40 to 0.56 , whereas in clinopyroxene-bearing dunite it varies from 0.22 to 0.26 , overlapping again the range of $\mathrm{Cr} \#$ in lherzolite and harzburgite.

The chemical variations observed in the cores of $\mathrm{Cr}$-spinel from the Ronda Ultramafic Massif can be simply explained in terms of high degrees of partial melting in the proximities and above of the recrystallization front. However, it also required melt-rock interactions in the lower plagioclase-tectonite domain, especially in depleted lithologies which acted as porous flow channels for melt migration. Core-to-rim variation as well as the composition of tiny spinel neoblast $(<50 \mu$ in diameter) further highlight the role played by melt-rock interactions and allow outline their extent up to and beyond the recrystallization front. 